\title{
Catalytic and capacity properties of nanocomposites based on cobalt oxide and nitrogen-doped carbon nanofibers
}

\author{
Olga Yu. Podyacheva a,*, Andrei I. Stadnichenko a,b, Svetlana A. Yashnik ${ }^{a}$, Olga A. Stonkus a,b, \\ Elena M. Slavinskaya a , Andrei I. Boronin a,b, Andrei V. Puzynin c, Zinfer R. Ismagilov a,c \\ a Boreskov Institute of Catalysis, Pr. Akademika Lavrentieva 5, Novosibirsk 630090, Russia \\ ${ }^{\mathrm{b}}$ Novosibirsk State University, Ul. Pirogova 2, Novosibirsk, 630090, Russia \\ ' Institute of Coal Chemistry and Material Science, Pr. Sovetskiy 18, Kemerovo 650000, Russia
}

\section{A R T I C L E I N F O}

Article history:

Received 27 March 2014

Accepted 9 April 2014

Published 20 June 2014

\section{Keywords:}

Cobalt oxide

Nitrogen-doped carbon nanofibers

Nanocomposite

CO oxidation

Capacity

\section{A B S T R A C T}

The nanocomposites based on cobalt oxide and nitrogen-doped carbon nanofibers (N-CNFs) with cobalt oxide contents of 10-90 wt\% were examined as catalysts in the CO oxidation and supercapacity electrodes. Depending on $\mathrm{Co}_{3} \mathrm{O}_{4}$ content, such nanocomposites have different morphologies of cobalt oxide nanoparticles, distributions over the bulk, and ratios of $\mathrm{Co}^{3+} / \mathrm{Co}^{2+}$ cations. The $90 \% \mathrm{Co}_{3} \mathrm{O}_{4}-\mathrm{N}-\mathrm{CNFs}$ nanocomposite showed the best activity because of the increased concentration of defects in N-CNFs. The capacitance of electrodes containing $10 \% \mathrm{Co}_{3} \mathrm{O}_{4}-\mathrm{N}-\mathrm{CNFs}$ was $95 \mathrm{~F} / \mathrm{g}$, which is 1.7 times higher than electrodes made from N-CNFs.

(C) 2014, Dalian Institute of Chemical Physics, Chinese Academy of Sciences. Published by Elsevier B.V. All rights reserved.

\section{Introduction}

Spinel cobalt oxide $\left(\mathrm{Co}_{3} \mathrm{O}_{4}\right)$ is one of the most well-known magnetic p-type semiconductors and has been successfully used in many fields, including heterogeneous catalysis, gas sensing, electrochemical devices, and lithium ion batteries [1-4]. Cobalt oxide is highly active in the low-temperature oxidation of carbon monoxide, which has been thoroughly studied for several decades because of the practical importance of this reaction for indoor air cleaning, purification of exhaust gases from motor vehicles, and gas sensing of CO levels. In addition, the low-temperature oxidation of $\mathrm{CO}$ is used as a model reaction to estimate the low-temperature activity of new catalysts and reveal the mechanisms of catalytic reactions [5]. Depending on the preparation method, cobalt oxide can be active in the oxidation of $\mathrm{CO}$ at different temperatures: at $20-50{ }^{\circ} \mathrm{C}$ in the case of $20 \% \mathrm{Co}_{3} \mathrm{O}_{4} / \gamma-\mathrm{Al}_{2} \mathrm{O}_{3}$ [6] or at negative temperatures in the case of $\mathrm{Co}_{3} \mathrm{O}_{4}$ nanorods $[7,8]$ or mesoporous $\mathrm{Co}_{3} \mathrm{O}_{4}$ [9].

A new approach to applying known systems for the development of advanced nanotechnologies is the design of nanocomposites composed of two or more nanomaterials that substantially differ in their chemical properties and morphologies. For example, $\mathrm{Co}_{3} \mathrm{O}_{4}-\mathrm{SiO}_{2}$ [10], $\mathrm{Co}_{3} \mathrm{O}_{4}-\mathrm{CuO}$ [11], or $\mathrm{Co}_{3} \mathrm{O}_{4}-\mathrm{CeO}_{2}$ [12] nanocomposites demonstrate higher activity and stability in the oxidation of $\mathrm{CO}$ than $\mathrm{Co}_{3} \mathrm{O}_{4}$.

Nanocomposites based on carbon nanomaterials and metals composed of Me-C or Me-O-C, where $\mathrm{Me}=\mathrm{Pt}, \mathrm{Pd}, \mathrm{Au}, \mathrm{Fe}, \mathrm{Co}, \mathrm{Mn}$, $\mathrm{V}, \mathrm{Ti}$, etc., are being studied now in various catalytic reactions. In the field of catalysis, a standard approach $[13,14]$ is employed for Me-C or Me-O-C nanocomposites: carbon is consid-

*Corresponding author. Fax: +7-383-3306219; E-mail: pod@catalysis.ru This work was supported by RFBR Grant 12-03-01091-a, Presidium RAS (Project 24.51), Presidium SB RAS (Project 36, Project 75). DOI: 10.1016/S1872-2067(14)60099-1 | http://www.sciencedirect.com/science/journal/18722067 | Chin. J. Catal., Vol. 35, No. 6, June 2014 
ered as a support and Me or Me-O are the supported catalytic components. Such nanocomposites have demonstrated high activity in environmentally friendly energy-generating processes [15-17], hydrogenation of cinnamaldehyde [18], decomposition of ammonia [19], Fischer-Tropsch reactions $[20,21]$, and other processes.

Some recent studies have been devoted to nanocomposites based on cobalt oxide and carbon nanomaterials, including $\mathrm{Co}_{3} \mathrm{O}_{4}$ /graphene for $\mathrm{Li}_{-} \mathrm{O}_{2}$ batteries [22] or $\mathrm{Co}_{3} \mathrm{O}_{4}$-carbon nanotubes (CNTs) for supercapacitors with electric double layers and pseudocapacitances [23].

Here, we investigate the catalytic and capacity properties of nanocomposites containing cobalt oxide and nitrogen-doped carbon nanofibers (N-CNFs). The introduction of nitrogen into the carbon structure is known to alter the physical and chemical properties of CNFs by increasing their conductivity and basicity. In addition, the presence of nitrogen-containing sites on the CNF surface facilitates stabilization of supported nano-sized metal particles [24-29].

\section{Experimental}

\subsection{Synthesis of N-CNFs, $\mathrm{Co}_{3} \mathrm{O}_{4}$, and $\mathrm{Co}_{3} \mathrm{O}_{4}-\mathrm{N}-\mathrm{CNFS}$ nanocomposites}

$\mathrm{N}-\mathrm{CNF}$ s (2.7 wt\% N) were synthesized by decomposition of a $50 \% \mathrm{C}_{2} \mathrm{H}_{4} / 50 \% \mathrm{NH}_{3}$ mixture over the $65 \% \mathrm{Ni}-25 \% \mathrm{Cu}-$

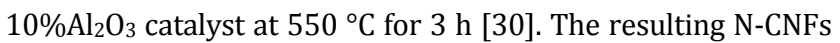
were treated with concentrated hydrochloric acid to remove the initial catalyst particles.

$\mathrm{Co}_{3} \mathrm{O}_{4}$ was synthesized by homogeneous precipitation from a $\mathrm{Co}\left(\mathrm{NO}_{3}\right)_{2}$ solution by a $\mathrm{NH}_{4} \mathrm{OH}$ solution at room temperature. The precipitate was filtered, carefully washed with distilled water, dried at room temperature, and calcined at $250{ }^{\circ} \mathrm{C}$ for 6 h.

$\mathrm{Co}_{3} \mathrm{O}_{4}$-N-CNFs nanocomposites were synthesized at room temperature by homogeneous precipitation from the $\mathrm{Co}\left(\mathrm{NO}_{3}\right)_{2}$ solution containing dispersed $\mathrm{N}-\mathrm{CNF}$ s by a $\mathrm{NH}_{4} \mathrm{OH}$ solution. The precipitate was filtered, carefully washed with distilled water, dried at room temperature, and calcined in air at $250{ }^{\circ} \mathrm{C}$ for $6 \mathrm{~h}$. The content of cobalt oxide in the resulting nanocomposites varied from 10 to $90 \mathrm{wt} \%$ (see Table 1).

\subsection{Physicochemical characterization}

X-Ray diffraction (XRD) patterns were taken on an HZG-4 diffractometer with monochromatic Co $K_{\alpha}$ radiation $\left(\lambda_{\mathrm{av}}=\right.$ $1.79021 \AA$ ).

Textural properties of the synthesized nanocomposites were studied using low-temperature nitrogen adsorption at $-196^{\circ} \mathrm{C}$ on a Micromeritics ASAP-2400 instrument. The specific surface area was calculated by the BET method.

Differential thermal analysis (DTA) was carried out on a Shimadzu DTG-60H analyzer. Samples (10 mg) were heated to $1000^{\circ} \mathrm{C}$ at a rate of $10{ }^{\circ} \mathrm{C} / \mathrm{min}$.

Thermoprogrammed reduction (TPR) experiments were carried out using the gas mixture containing 10\% $\mathrm{H}_{2}-90 \% \mathrm{Ar}$
Table 1

Characteristics of $\mathrm{Co}_{3} \mathrm{O}_{4}-\mathrm{N}-\mathrm{CNF}$ nanocomposites.

\begin{tabular}{lcc}
\hline Sample & $A_{\text {BET }}\left(\mathrm{m}^{2} / \mathrm{g}\right)$ & $\mathrm{XRD}$ \\
\hline $\mathrm{Co}_{3} \mathrm{O}_{4}$ & 88 & $\mathrm{Co}_{3} \mathrm{O}_{4}: a=8.086 \AA$ \\
$90 \% \mathrm{Co}_{3} \mathrm{O}_{4}-\mathrm{N}-\mathrm{CNFs}$ & 100 & $\mathrm{Co}_{3} \mathrm{O}_{4}: a=8.069 \AA$ \\
$50 \% \mathrm{Co}_{3} \mathrm{O}_{4}-\mathrm{N}-\mathrm{CNFs}$ & 190 & $\mathrm{C}: d / n=3.408 \AA \AA \mathrm{Co}_{3} \mathrm{O}_{4}: a=8.081 \AA$ \\
$10 \% \mathrm{Co}_{3} \mathrm{O}_{4}-\mathrm{N}-\mathrm{CNFs}$ & 274 & $\mathrm{C}: d / n=3.425 \AA \mathrm{Co}_{3} \mathrm{O}_{4}: a=8.083 \AA$ \\
$\mathrm{N}-\mathrm{CNFs}$ & 275 & $\mathrm{C}: d / n=3.414 \AA$ \\
\hline
\end{tabular}

with a flow rate of $30 \mathrm{ml} / \mathrm{min}$ in a laboratory instrument equipped with a thermal conductivity detector. The temperature was raised from 25 to $800{ }^{\circ} \mathrm{C}$ at a rate of $10^{\circ} \mathrm{C} / \mathrm{min}$. The $\mathrm{H}_{2}$-TPR spectra were recorded after pretreatment of the samples in $\mathrm{Ar}$ at room temperature or after treatment in a mixture of $20 \% \mathrm{O}_{2}-80 \% \mathrm{Ar}$ at $200{ }^{\circ} \mathrm{C}$ for $1 \mathrm{~h}$. After pretreatment, the samples were cooled to room temperature and flushed with an Ar flow. The mass of the samples was $20 \mathrm{mg}$ and their particle size was $0.25-0.5 \mathrm{~mm}$. The water produced during the TPR experiment was removed using a cold trap.

Transmission electron microscopy (TEM) was performed with transmission electron microscopes JEOL JEM-2010 and JEM-2200FS with an accelerating voltage of $200 \mathrm{kV}$ and a spatial lattice resolution of 1.4 and $1 \AA$, respectively. The samples were deposited on copper grids $3 \mathrm{~mm}$ in diameter, which were covered with a carbon film with a set of holes. Alcohol suspensions of the samples were dispersed by ultrasound and deposited onto the substrates.

X-Ray photoelectron spectroscopy (XPS) measurements were made on an ES-300 (KRATOS Analytical) photoelectron spectrometer with $\mathrm{Al} K_{\alpha}$ line $(h v=1486.6 \mathrm{eV})$. The energy scale of the spectrometer was calibrated against the binding energies of the $\mathrm{Au} 4 f_{7 / 2}$ line at $84.0 \mathrm{eV}$ and the $\mathrm{Cu} 2 p_{3 / 2}$ line at $932.7 \mathrm{eV}$. Spectral calibration for the $\mathrm{Co}_{3} \mathrm{O}_{4}$ sample was performed using $E_{\mathrm{b}}(\mathrm{C} 1 s)=284.8 \mathrm{eV}$. Other samples were not characterized by the charging effect. Control of the surface chemical composition was attained using survey spectra in the range of $0-1100 \mathrm{eV}$. We acquired narrow scans using a pass energy of $25 \mathrm{eV}$ and a $0.1-\mathrm{eV}$ step to analyze the composition and chemical state of the elements. The quantitative analysis of the composition was made on the basis of calculating the integral intensity of the corresponding narrow lines in the XPS spectra, taking into account the atomic sensitivity of each element. We performed decomposition of the spectra into components, smoothing, normalization, and other spectral treatment procedures with the aid of the original XPS Calc package, which was successfully applied to various systems including N-CNFs materials [28-30].

\subsection{Catalytic testing}

The catalytic properties of the samples were tested using the temperature-programmed reaction (light-off) in an automated setup with a stainless steel flow reactor and mass spectrometric analysis of the gas mixture. A sample $0.25 \mathrm{~cm}^{3}$ in volume with particle sizes ranging from 0.25 to $0.5 \mathrm{~mm}$ was placed into the reactor. The reaction mixture containing 0.2 vol\% CO-1.0 vol\% $\mathrm{O}_{2}-0.5$ vol\% $\mathrm{Ne} / \mathrm{He}$ was fed at a rate of 1000 $\mathrm{cm}^{3} / \mathrm{min}\left(240000 \mathrm{~h}^{-1}\right)$ to the initial catalyst that was cooled to 
$-15^{\circ} \mathrm{C}$. We used cyclical heating and cooling in the reaction mixture. The catalyst was heated from -15 to $250{ }^{\circ} \mathrm{C}$ at a rate of $10^{\circ} \mathrm{C} / \mathrm{min}$ with subsequent cooling and repeated heating, after which the catalyst was cooled in He. The concentrations of $\mathrm{CO}$, $\mathrm{O}_{2}$, and $\mathrm{CO}_{2}$ were monitored over the course of the reaction. The concentrations were measured in each point at a frequency of $0.34 \mathrm{~Hz}$.

\subsection{Capacity testing}

The electrochemical properties of the nanocomposites were studied using the cyclic voltammetry method. First, a cell was examined by means of a comparison with the readings of the same electrodes obtained for the known cell [31]. A symmetric two-electrode cell was used for the measurements of the $\mathrm{N}$-CNFs samples, whereas an asymmetric two-electrode cell was used in the case of $\mathrm{Co}_{3} \mathrm{O}_{4}-\mathrm{N}$-CNFs nanocomposites. In the asymmetric cell, we used an electrode made of microporous carbon nanomaterial Kemerit-5 with a known capacity of 348 $\mathrm{F} / \mathrm{g}$ at $10 \mathrm{mV} / \mathrm{s}$. Aqueous solutions of potassium hydroxide (6 mol/L) served as the electrolyte. The electrodes of the supercapacitors were prepared from a mixture of $80 \% \mathrm{~N}-\mathrm{CNF}$ or $\mathrm{Co}_{3} \mathrm{O}_{4}-\mathrm{N}-\mathrm{CNF}$ and $20 \mathrm{wt} \%$ acetylene black.

\section{Results and discussion}

\subsection{Nitrogen adsorption, $X R D$, and DTA results}

A decrease in the cobalt oxide content in the nanocomposite from $90 \%$ to $10 \%$ was accompanied by a monotonic increase in its specific surface area from 100 to $275 \mathrm{~m}^{2} / \mathrm{g}$. The XRD data indicated the formation of $\mathrm{Co}_{3} \mathrm{O}_{4}$ phase in all nanocomposites (see Table 1).

The DTA curve of $\mathrm{Co}_{3} \mathrm{O}_{4}$ (Fig. 1) showed a single endothermic peak at $919^{\circ} \mathrm{C}$, which can be attributed to $\mathrm{Co}_{3} \mathrm{O}_{4}$ decomposition into $\mathrm{CoO}$ and $\mathrm{O}$ according to the literature $[32,33]$.

The combustion resistance of N-CNFs is described by Fig. 1 (curve 2); it has a single exothermic peak at $508{ }^{\circ} \mathrm{C}$, which agrees with the DTA data for carbon nanomaterials reported in the literature $[34,35]$. The absence of additional exothermic

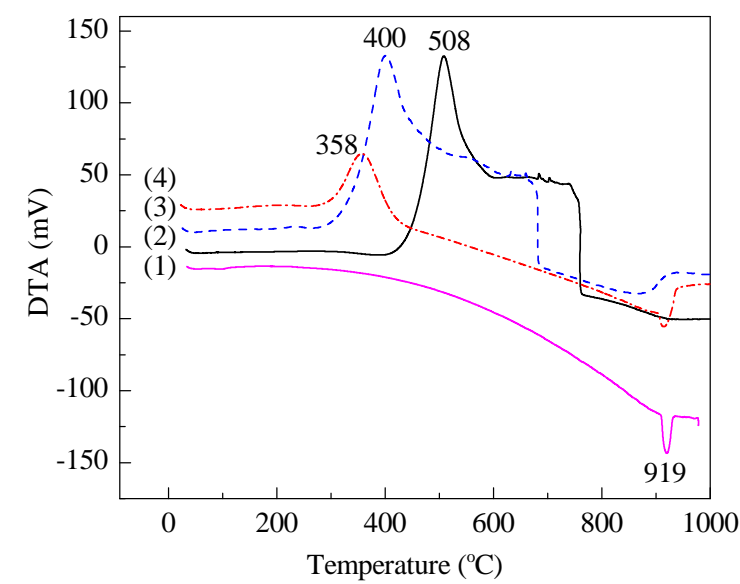

Fig. 1. DTA curves of (1) $\mathrm{Co}_{3} \mathrm{O}_{4},(2) \mathrm{N}-\mathrm{CNFs}$, (3) $10 \% \mathrm{Co}_{3} \mathrm{O}_{4}-\mathrm{N}-\mathrm{CNFs}$, and (4) $90 \% \mathrm{Co}_{3} \mathrm{O}_{4}-\mathrm{N}-\mathrm{CNFs}$. peaks indicates the homogeneity of N-CNFs. Curves (3) and (4), which correspond to nanocomposites, exhibit a weak exothermic peak at $\sim 200^{\circ} \mathrm{C}$, whereas the main peak, corresponding to combustion of N-CNFs, shifted toward low temperatures by $\sim 100{ }^{\circ} \mathrm{C}$ in the case of $10 \% \mathrm{Co}_{3} \mathrm{O}_{4}-\mathrm{N}-\mathrm{CNFs}$ and by $\sim 150{ }^{\circ} \mathrm{C}$ in the case of $90 \% \mathrm{Co}_{3} \mathrm{O}_{4}-\mathrm{N}-\mathrm{CNF}$.

\subsection{TEM results}

The $\mathrm{Co}_{3} \mathrm{O}_{4}$ sample was composed of spherical nanoparticles 3-20 $\mathrm{nm}$ in diameter and nanoparticles with flattened or nanorod-like shapes with widths of 3-7 nm and lengths of 15-40 nm (Fig. 2(a)). A typical selected area electron diffraction pattern for an aggregate of particles is ring-shaped (see the insert in Fig. 2(a)); the measured interplanar spacings $\left(d_{111}=4.67 \AA\right.$, $d_{220}=2.86 \AA, d_{311}=2.44 \AA$, and $d_{400}=2.02 \AA$ ) correspond to the $\mathrm{Co}_{3} \mathrm{O}_{4}$ phase with a spinel-like structure $(C \mathrm{C}=150805$ in Inorganic Crystal Structure Database, 2011, Fachinformationszentrum Karlsruhe, D-76344 Eggenstein-Leopoldshafen (Germany)).

$\mathrm{Co}_{3} \mathrm{O}_{4}-\mathrm{N}-\mathrm{CNF}$ nanocomposites comprise CNFs (100-200 $\mathrm{nm}$ in length and approximately $50 \mathrm{~nm}$ in width) with platelet and herringbone structures, which are covered with $\mathrm{Co}_{3} \mathrm{O}_{4}$ nanoparticles. The morphology of such nanocomposites strongly depends on the cobalt oxide content. In the case of $90 \% \mathrm{Co}_{3} \mathrm{O}_{4}-\mathrm{N}-\mathrm{CNFs}$ (Fig. 2(b)), the surface of $\mathrm{N}-\mathrm{CNF}$ s is covered with cobalt oxide nanoparticles; in addition, regions of agglomerated cobalt oxide particles are observed here, as was the case for the $\mathrm{Co}_{3} \mathrm{O}_{4}$ sample. The size and shape of the $\mathrm{Co}_{3} \mathrm{O}_{4}$ nanoparticles in 90\% $\mathrm{Co}_{3} \mathrm{O}_{4}-\mathrm{N}-\mathrm{CNF}$ did not change in comparison with

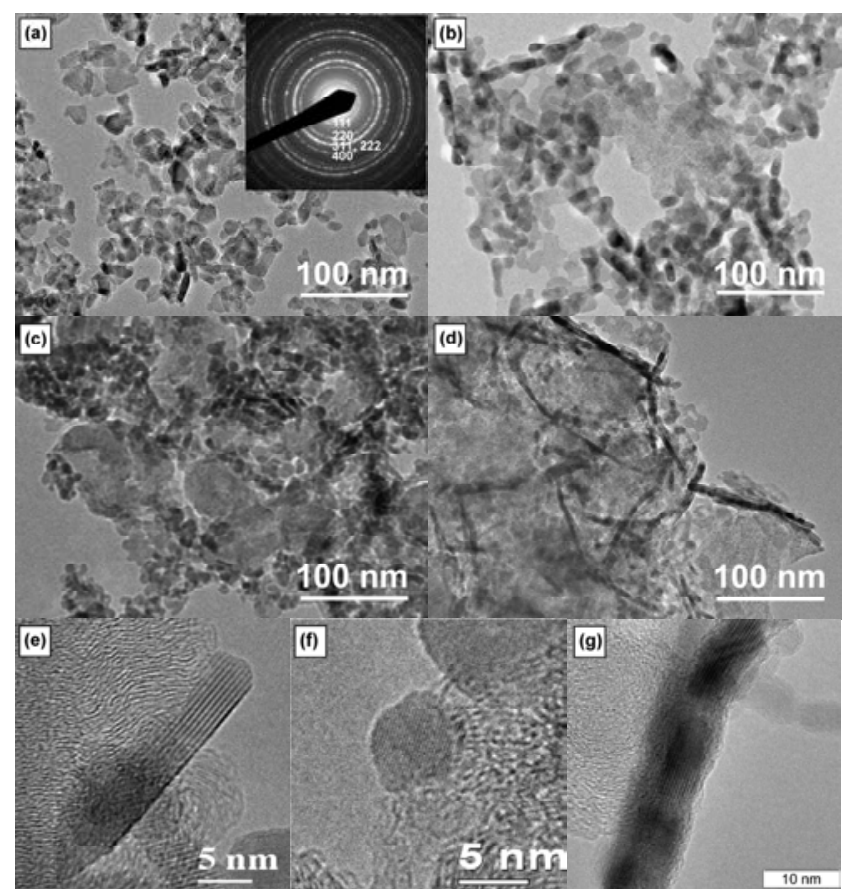

Fig. 2. TEM images of (a) $\mathrm{Co}_{3} \mathrm{O}_{4}$ and (b-d) $\mathrm{Co}_{3} \mathrm{O}_{4}-\mathrm{N}-\mathrm{CNFs}$ nanocomposites containing $90 \%, 50 \%$, and $10 \% \mathrm{Co}_{3} \mathrm{O}_{4}$, respectively; (e-f) HRTEM images of flattened and spherical $\mathrm{Co}_{3} \mathrm{O}_{4}$ nanoparticles on the $\mathrm{N}-\mathrm{CNF}$ surface in $90 \% \mathrm{Co}_{3} \mathrm{O}_{4}-\mathrm{N}-\mathrm{CNFs}$, respectively; (g) HRTEM image of monolithic $\mathrm{Co}_{3} \mathrm{O}_{4}$ nanoparticle in $10 \% \mathrm{Co}_{3} \mathrm{O}_{4}$-N-CNFs. 
the $\mathrm{Co}_{3} \mathrm{O}_{4}$ sample (Fig. 2(b), (e), and (f)). A decrease in the cobalt oxide content to $50-10 \mathrm{wt} \%$ produced a uniform distribution in the bulk of the nanocomposites and prevented agglomeration of $\mathrm{CO}_{3} \mathrm{O}_{4}$ nanoparticles (Fig. 2(c) and (d)). These results indicate that interaction between $\mathrm{Co}_{3} \mathrm{O}_{4}$ and $\mathrm{N}$-CNFs is stronger than that between $\mathrm{Co}_{3} \mathrm{O}_{4}$ particles [36]. Furthermore, a decrease in the cobalt oxide content in the nanocomposites resulted in the formation of extended $\mathrm{Co}_{3} \mathrm{O}_{4}$ particles with lengths up to $100 \mathrm{~nm}$ and widths close to $10 \mathrm{~nm}$. The largest number of such particles was observed for the $10 \% \mathrm{Co}_{3} \mathrm{O}_{4}$-N-CNFs sample (Fig. 2(d)). One can see from the HRTEM images (Fig. 2(g)) that the extended particles are monolithic and are formed because of intergrowth of $\mathrm{Co}_{3} \mathrm{O}_{4}$ nanoparticles on the N-CNF surface.

\subsection{XPS results}

Figure 3 shows the Co $2 p$ XPS spectra after the spectroscopic treatment, including background subtraction and deconvolution into components. The initial spectra (not shown here) demonstrated that all of the studied samples had similar states of cobalt; the line shape of the Co $2 p$ spectrum, the $E_{\mathrm{b}}$ (Co $2 p_{3 / 2}$ ) $\approx 780 \mathrm{eV}$, and the presence of indistinct satellite structure in the region of $786-790 \mathrm{eV}$ indicated the formation of $\mathrm{Co}_{3} \mathrm{O}_{4}$
[37-40]. $\mathrm{Co}^{2+}$ and $\mathrm{Co}^{3+}$ are known to have similar binding energy $[37,38]$, so the decomposition of the spectrum into individual components was hindered. Decomposition of the Co $2 p$ spectrum into components with a binding energy of $779.8 \mathrm{eV}$ for $\mathrm{Co}^{3+}$ and $782.1 \mathrm{eV}$ for $\mathrm{Co}^{2+}$ has been reported in the literature [41]. We used these data for the decomposition of the full Co $2 p$ line, which allowed us to extract doublets that can be attributed to cobalt in the oxidation states +3 and +2 and also two doublets of the satellite structures. As seen in Fig. 3, the $\mathrm{Co}^{3+} / \mathrm{Co}^{2+}$ ratio in the initial $\mathrm{Co}_{3} \mathrm{O}_{4}$ sample corresponds to the spinel structure, and the intensity ratio of the main peaks with $E_{\mathrm{b}}\left(\mathrm{Co} 2 p_{3 / 2}\right) \approx 780$ and $782 \mathrm{eV}$, relating to $\mathrm{Co}^{3+}$ and $\mathrm{Co}^{2+}$, respectively, is about 2. The introduction of N-CNFs into the nanocomposites decreased the intensity of the components relating to $\mathrm{Co}^{3+}$ virtually by a factor of 2 ; a minimum amount of $\mathrm{Co}^{3+}$ was observed for the $10 \% \mathrm{Co}_{3} \mathrm{O}_{4}-\mathrm{N}-\mathrm{CNF}$ sample. The data in the Table 2 testify that the chemical interaction occurred between $\mathrm{Co}_{3} \mathrm{O}_{4}$ nanoparticles and N-CNFs.

The $\mathrm{C} 1 s$ spectra shown in Fig. 4 completely confirm the above conclusions related to the interaction of $\mathrm{N}$-CNFs with cobalt oxide nanoparticles in nanocomposites. One can see from the C $1 s$ spectrum of N-CNFs a maximum at $284.5 \mathrm{eV}$, which is typical of the carbon $\mathrm{sp}^{2}$ structures [28-30].
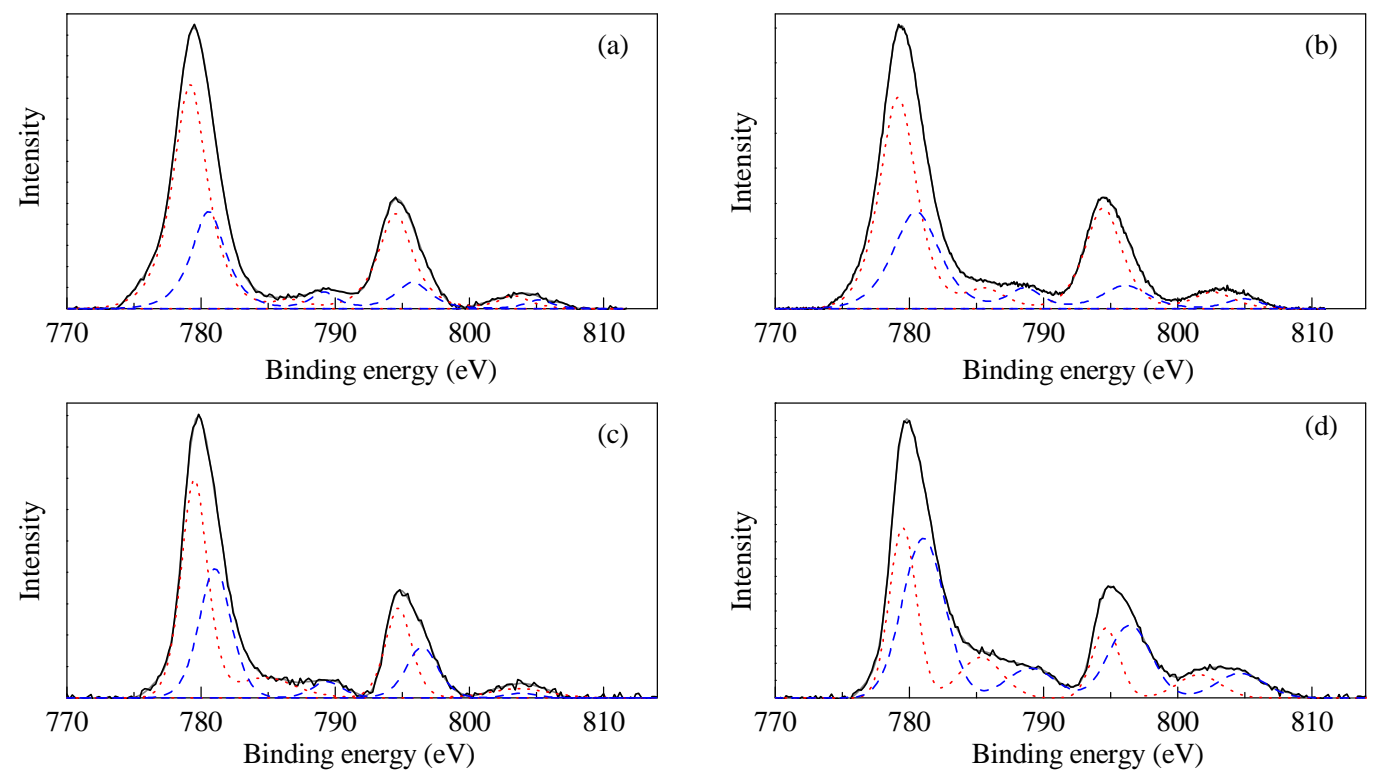

Fig. 3. Decomposition of Co $2 p$ XPS spectra into individual components for (a) $\mathrm{Co}_{3} \mathrm{O}_{4}$ and (b-d) $\mathrm{Co}_{3} \mathrm{O}_{4}-\mathrm{N}-\mathrm{CNFs}$ nanocomposites containing $90 \%$, $50 \%$, and $10 \% \mathrm{Co}_{3} \mathrm{O}_{4}$, respectively. Spectral characteristics of the $\mathrm{Co} 2 p$ line for $\mathrm{Co}^{3+}$ ions are shown in red dot lines, and peaks characterizing the state of $\mathrm{Co}^{2+}$ ions are shown in blue dash lines.

Table 2

The ratio of different cobalt, carbon, and nitrogen species in the samples according to XPS.

\begin{tabular}{|c|c|c|c|c|c|c|c|c|}
\hline \multirow{2}{*}{ Sample } & \multicolumn{3}{|c|}{$\mathrm{Co}^{n+}$ amount (\%) } & \multicolumn{3}{|c|}{ Carbon species amount (\%) } & \multirow{2}{*}{$\begin{array}{c}\mathrm{N} \\
\text { (at\%) }\end{array}$} & \multirow{2}{*}{$\begin{array}{c}\mathrm{N} \text { species ratioc } \\
\mathrm{N}_{\mathrm{Py}}: \mathrm{N}_{\mathrm{Pyr}}: \mathrm{N}_{\mathrm{Q}}: \mathrm{N}_{\mathrm{ox}}\end{array}$} \\
\hline & $\mathrm{Co}^{3+}$ & $\mathrm{Co}^{2+}$ & $\mathrm{Co}^{3+} / \mathrm{Co}^{2+}$ & $\mathrm{sp}^{2}(284.5 \mathrm{eV})^{\mathrm{a}}$ & $\mathrm{sp}^{3}(285.5 \mathrm{eV})$ & $\mathrm{CO}_{x}(287-289 \mathrm{eV})$ & & \\
\hline$\overline{\mathrm{Co}_{3} \mathrm{O}_{4}}$ & 70.53 & 29.47 & 2.39 & 0.00 & $88.39 \mathrm{~b}$ & 11.61 & 0.4 & - \\
\hline $90 \% \mathrm{Co}_{3} \mathrm{O}_{4}-\mathrm{N}-\mathrm{CNFS}$ & 66.14 & 33.86 & 1.95 & 56.91 & 31.90 & 11.19 & 0.6 & $0.64: 0.24: 0.12: 0.00$ \\
\hline $50 \% \mathrm{Co}_{3} \mathrm{O}_{4}-\mathrm{N}-\mathrm{CNFS}$ & 60.53 & 39.47 & 1.53 & 73.75 & 14.45 & 11.80 & 2.2 & $0.36: 0.17: 0.20: 0.27$ \\
\hline $10 \% \mathrm{Co}_{3} \mathrm{O}_{4}-\mathrm{N}-\mathrm{CNFS}$ & 42.37 & 57.63 & 0.74 & 92.05 & 0.86 & 7.09 & 1.8 & $0.40: 0.24: 0.30: 0.06$ \\
\hline $\mathrm{N}-\mathrm{CNFS}$ & - & - & - & 92.76 & 0.00 & 7.24 & 2.3 & $0.44: 0.06: 0.41: 0.09$ \\
\hline
\end{tabular}

a The main peak and shake-up satellite were summed to calculate the amount of $\mathrm{sp}^{2}$ carbon.

b In the case of $\mathrm{Co}_{3} \mathrm{O}_{4}, \mathrm{sp}^{3}$ carbon is represented by amorphous surface carbon deposits with $E_{\mathrm{b}}(\mathrm{C} 1 \mathrm{~s})=284.8 \mathrm{eV}$.

c Atomic ratio of $\mathrm{N}$ states. $\mathrm{N}_{\mathrm{Py}}-$ pyridine $\mathrm{N}$; $\mathrm{N}_{\mathrm{Pyr}}-$ pyrrole $\mathrm{N} ; \mathrm{N}_{\mathrm{Q}}$-graphite-like $\mathrm{N} ; \mathrm{N}_{\mathrm{ox}}$ - oxidized state $\mathrm{N}$. 

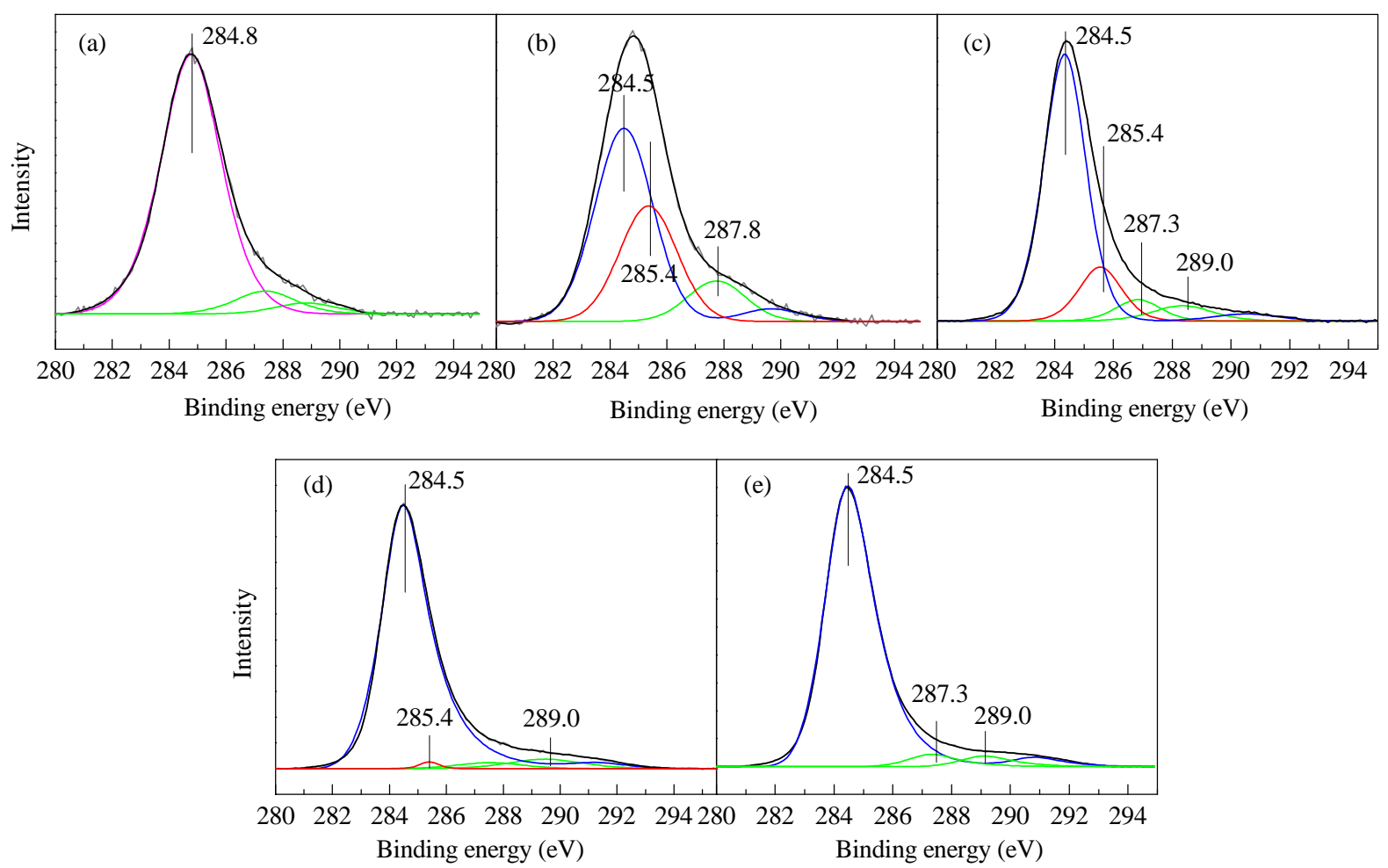

Fig. 4. Decomposition of $\mathrm{C} 1 s$ XPS spectra into individual components for (a) $\mathrm{Co}_{3} \mathrm{O}_{4}$, (b-d) $\mathrm{Co}_{3} \mathrm{O}_{4}-\mathrm{N}-\mathrm{CNFs}$ nanocomposites containing $90 \%$, 50\%, and $10 \% \mathrm{Co}_{3} \mathrm{O}_{4}$, respectively, and (e) $\mathrm{N}$-CNFs.

Low-intensity peaks with $E_{\mathrm{b}}(\mathrm{C} 1 s)>287 \mathrm{eV}$ correspond to the surface oxygen-containing groups. When going to nanocomposites (Fig. 4(b)-(d)), the C $1 s$ spectrum shows not only the carbon $\mathrm{sp}^{2}$ structures but also a component with $E_{\mathrm{b}}(\mathrm{C} 1 s)=285.4$ $\mathrm{eV}$, which can reliably be attributed to carbon in the $\mathrm{sp}^{3}$ hybridized state. Thus, three different states of carbon were detected in $\mathrm{Co}_{3} \mathrm{O}_{4}-\mathrm{N}-\mathrm{CNF}$ nanocomposites: carbon with $\mathrm{sp}^{2}$ or $\mathrm{sp}^{3}$ hybridization and carbon as a component of the oxygen-containing groups. As seen from Table 2, the amount of $\mathrm{sp}^{2}$ carbon decreased when the cobalt oxide content in the nanocomposite was increased and the amount of carbon with $\mathrm{sp}^{3}$ hybridization and carbon in the oxygen-containing groups increased. For $90 \% \mathrm{Co}_{3} \mathrm{O}_{4}-\mathrm{N}-\mathrm{CNF}$, the contribution of $\mathrm{sp}^{3}$ carbon is maximized compared with other nanocomposites, which indicates a pronounced inhomogeneity and an increased concentration of defects in N-CNFs in this case. This finding suggests that the interaction of $\mathrm{Co}_{3} \mathrm{O}_{4}$ nanoparticles with $\mathrm{N}$-CNFs proceeds via $\mathrm{sp}^{3}$ carbon because a direct correlation is observed between the cobalt oxide amount in nanocomposite and the amount of carbon in the $\mathrm{sp}^{3}$ hybridized state.

The $01 s$ spectra also demonstrated that nanocomposites have a complicated line shape. A broad line with $E_{\mathrm{b}} \approx 530 \mathrm{eV}$ appeared; it has two maxima corresponding to the lattice 0 with $E_{\mathrm{b}}=529.7-530 \mathrm{eV}$ and $O$ with $E_{\mathrm{b}}=531 \mathrm{eV}$, which can be a component of $\mathrm{OH}$ groups, chemisorbed water [38], or $0^{-}$oxygen ions with low coordination on the surface of samples $[39,42]$. A more detailed analysis of $01 s$ spectra is beyond the scope of this paper; the decomposition of the $01 \mathrm{~s}$ line into components is not attempted in this work.

An interesting behavior of the states of elements was observed in the $\mathrm{N} 1 s$ spectra of the samples shown in Fig. 5. As was shown in our earlier studies [28-30], $\mathrm{N}$ in N-CNFs can be in pyridine, pyrrole, graphite-like, and oxidized states; the pyridine and graphite-like states are the most predominant. In $\mathrm{Co}_{3} \mathrm{O}_{4}-\mathrm{N}$-CNFs nanocomposites, all states of $\mathrm{N}$ are retained, but their ratio changes: the amount of graphite-like $\mathrm{N}$ decreases and that of pyrrole $\mathrm{N}$ increases (Table 2). A decrease in the $\mathrm{N}_{\mathrm{Q}} /\left(\mathrm{N}_{\mathrm{Py}}+\mathrm{N}_{\text {Pyr }}\right)$ ratio indicates a lower ordering of N-CNFs in nanocomposites and, accordingly, a higher concentration of defects.

\section{4. $\mathrm{H}_{2}$-TPR results}

Figure 6 shows the $\mathrm{H}_{2}$-TPR curves for the samples after treatment in $\mathrm{Ar}$ and in the $\mathrm{O}$-containing medium. An intense absorption of $\mathrm{H}$ occurs in the temperature range of $250-400{ }^{\circ} \mathrm{C}$ and shows as two poorly resolved peaks with maxima at 285-300 and $355-360{ }^{\circ} \mathrm{C}$. The data obtained agree well with the available literature data $[43,44]$ and correspond to the two-step reduction of $\mathrm{Co}_{3} \mathrm{O}_{4} \rightarrow \mathrm{CoO} \rightarrow$ Co $[41,45,46]$. The oxidative pretreatment of $\mathrm{Co}_{3} \mathrm{O}_{4}$ increases the surface area and shifts the maximum of the low-temperature peak from 305 to $285{ }^{\circ} \mathrm{C}$ in the $\mathrm{H}_{2}$-TPR spectrum. An additional low-intensity peak also appears at $190^{\circ} \mathrm{C}$, which can be attributed to the weakly bound surface oxygen. In the case of $\mathrm{Co}_{3} \mathrm{O}_{4}-\mathrm{N}$-CNFs nanocomposites, the overall shape of the $\mathrm{H}_{2}$-TPR curves is retained after the 

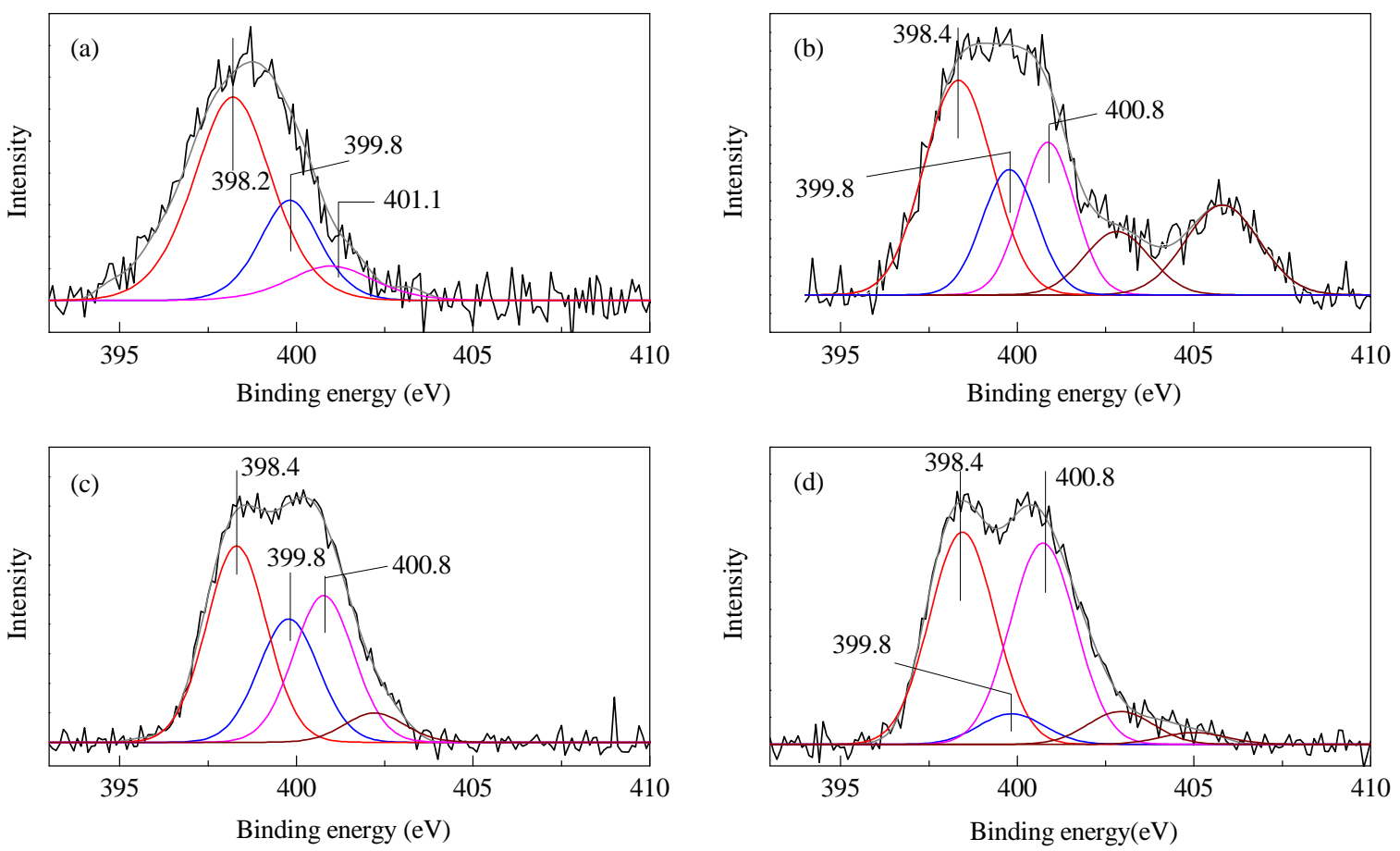

Fig. 5. $\mathrm{N} 1 s$ XPS spectra of (a-c) $\mathrm{Co}_{3} \mathrm{O}_{4}$-N-CNFs nanocomposites containing $90 \%, 50 \%$, and $10 \% \mathrm{Co}_{3} \mathrm{O}_{4}$, respectively, and (d) $\mathrm{N}$-CNFs.
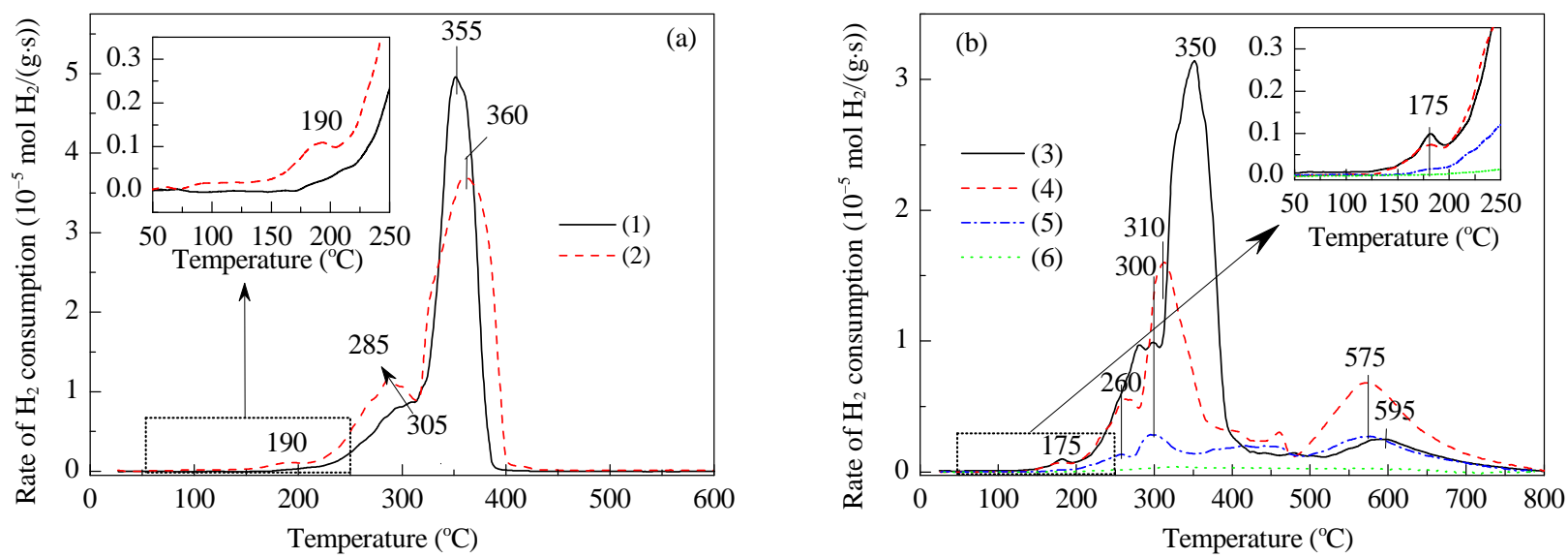

Fig. 6. $\mathrm{H}_{2}$-TPR curves for $\mathrm{Co}_{3} \mathrm{O}_{4}$ (a) and $\mathrm{Co}_{3} \mathrm{O}_{4}-\mathrm{N}$-CNFs nanocomposites (b) after treatment in $\mathrm{Ar}$ at $25{ }^{\circ} \mathrm{C}(1)$ or $\mathrm{O}_{2}+\mathrm{Ar}(1: 4)$ at $200{ }^{\circ} \mathrm{C}\left((2) \mathrm{Co}_{3} \mathrm{O}_{4},(3)\right.$ $90 \% \mathrm{Co}_{3} \mathrm{O}_{4}-\mathrm{N}-\mathrm{CNFs}$, (4) $50 \% \mathrm{Co}_{3} \mathrm{O}_{4}-\mathrm{N}-\mathrm{CNFs}$, (5) $10 \% \mathrm{Co}_{3} \mathrm{O}_{4}-\mathrm{N}-\mathrm{CNFs}$, and (6) N-CNFs).

oxidative treatment. However, there are some distinctions from bulk $\mathrm{Co}_{3} \mathrm{O}_{4}$. First, all three maxima are shifted to the low-temperature region, and second, a new extended low-intensity peak with the maximum at $575-595{ }^{\circ} \mathrm{C}$ appears in the spectrum. The new adsorption peak is most likely caused by the reduction of $\mathrm{Cu}$ (II) and $\mathrm{Ni}(\mathrm{II})$ impurity cations, which are components of the N-CNF growth catalyst.

The amount of absorbed $\mathrm{H}$ depends on the pretreatment and composition of the sample. From Table 3, a maximum amount was observed for $\mathrm{Co}_{3} \mathrm{O}_{4}$ after the oxidative treatment $\left(\mathrm{H}_{2} / \mathrm{Co}=1.45\right)$, while a minimum amount was observed in the case of $10 \% \mathrm{Co}_{3} \mathrm{O}_{4}-\mathrm{N}-\mathrm{CNFs}\left(\mathrm{H}_{2} / \mathrm{Co}=0.78\right)$. A theoretical $\mathrm{H}_{2} / \mathrm{Co}$ ratio for $\mathrm{Co}_{3} \mathrm{O}_{4}$ is equal to 1.33 . These data indicate that the
$\mathrm{Co}^{3+} / \mathrm{Co}^{2+}$ stoichiometry changed substantially when going from $\mathrm{Co}_{3} \mathrm{O}_{4}$ to $\mathrm{Co}_{3} \mathrm{O}_{4}-\mathrm{N}-\mathrm{CNFS}$ nanocomposites, which completely agrees with the XPS data.

\subsection{Catalytic properties of $\mathrm{Co}_{3} \mathrm{O}_{4}-\mathrm{N}$-CNFs in $\mathrm{CO}$ oxidation}

A comparison of catalytic properties of the samples in the CO oxidation was made using the temperature at which $50 \%$ CO conversion was reached $\left(T_{50}\right)$. From Fig. $7(a)$, one can see that the activity of the samples during the first heating was not strongly different; there is a small decrease of activity in the following series: $\mathrm{Co}_{3} \mathrm{O}_{4}\left(T_{50}=135{ }^{\circ} \mathrm{C}\right)>90 \% \mathrm{Co}_{3} \mathrm{O}_{4}-\mathrm{N}-\mathrm{CNFs}\left(T_{50}\right.$ $\left.=142{ }^{\circ} \mathrm{C}\right) \sim 50 \% \mathrm{Co}_{3} \mathrm{O}_{4}-\mathrm{N}-\mathrm{CNFs}\left(\mathrm{T}_{50}=146{ }^{\circ} \mathrm{C}\right)>10 \% \mathrm{Co}_{3} \mathrm{O}_{4}-$ 
Table 3

$\mathrm{H}_{2}$-TPR data of the samples.

\begin{tabular}{lccc}
\hline Sample & Treatment & $\begin{array}{c}\mathrm{H}_{2} / \text { Co molar ratio } \\
\text { at } 100-430{ }^{\circ} \mathrm{C}\end{array}$ & $\begin{array}{c}\text { Temperature of } \\
\text { reduction steps }\left({ }^{\circ} \mathrm{C}\right)\end{array}$ \\
\hline $\mathrm{Co}_{3} \mathrm{O}_{4}$ & $\mathrm{Ar}$ & 1.18 & $-/ 305 / 360 /-$ \\
& $\mathrm{O}_{2}+\mathrm{Ar}$ & 1.45 & $190 / 285 / 355 /-$ \\
$90 \% \mathrm{Co}_{3} \mathrm{O}_{4}-\mathrm{N}-\mathrm{CNFs}$ & $\mathrm{O}_{2}+\mathrm{Ar}$ & 1.33 & $175 / 260 / 350 / 595$ \\
$50 \% \mathrm{Co}_{3} \mathrm{O}_{4}-\mathrm{N}-\mathrm{CNFs}$ & $\mathrm{O}_{2}+\mathrm{Ar}$ & 1.00 & $175 / 260 / 310 / 575$ \\
$10 \% \mathrm{Co}_{3} \mathrm{O}_{4}-\mathrm{N}-\mathrm{CNFS}$ & $\mathrm{O}_{2}+\mathrm{Ar}$ & 0.78 & $175 / 260 / 300 / 595$ \\
$\mathrm{~N}-\mathrm{CNFs}$ & $\mathrm{O}_{2}+\mathrm{Ar}$ & - & - \\
\hline
\end{tabular}

CNFs $\left(T_{50}=162{ }^{\circ} \mathrm{C}\right)$. N-CNFs did not show activity in the $\mathrm{CO}$ oxidation over the studied temperature range. The samples were activated during the first heating cycle; their activity increased considerably and a maximum activity was observed for the $90 \% \mathrm{Co}_{3} \mathrm{O}_{4}-\mathrm{N}-\mathrm{CNF}$ s nanocomposite (Fig. 7(b)). The samples with high content of cobalt oxide yielded the unusual, U-shaped temperature dependence of $\mathrm{CO}$ conversion. The temperature curve of $\mathrm{CO}$ conversion can be divided into three phases: (1) starting from $-15^{\circ} \mathrm{C}$, activity increases and attains a maximum at $\sim 20^{\circ} \mathrm{C}$; (2) starting from $20^{\circ} \mathrm{C}, \mathrm{CO}$ conversion decreases to a minimum value at $80-90{ }^{\circ} \mathrm{C}$; (3) at temperatures above $80-90$ ${ }^{\circ} \mathrm{C}$, CO conversion increases to $100 \%$. This dependence was
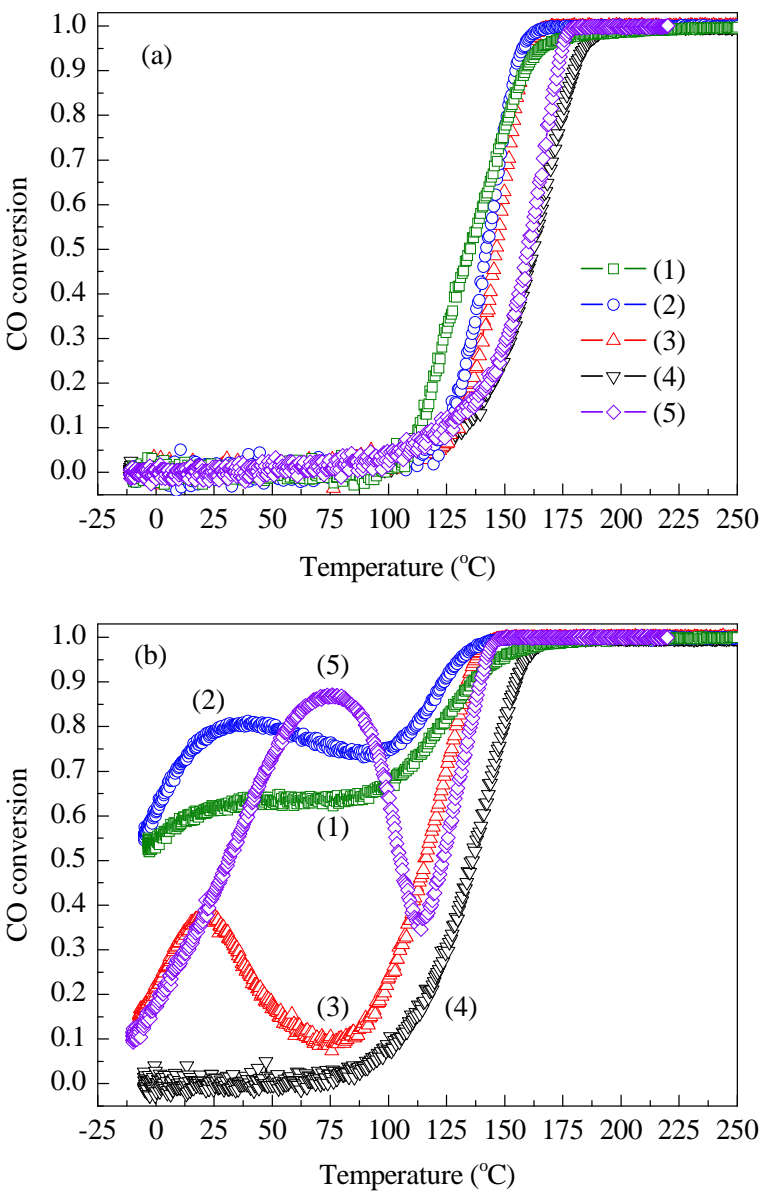

Fig. 7. Temperature dependences of $\mathrm{CO}$ conversion during the first (a) and second (b) heating cycles at $240000 \mathrm{~h}^{-1}$ over $\mathrm{Co}_{3} \mathrm{O}_{4}$ (1), $90 \% \mathrm{Co}_{3} \mathrm{O}_{4}-\mathrm{N}-\mathrm{CNFs}(2), 50 \% \mathrm{Co}_{3} \mathrm{O}_{4}-\mathrm{N}-\mathrm{CNFs}(3)$, and $10 \% \mathrm{Co}_{3} \mathrm{O}_{4}-\mathrm{N}-\mathrm{CNFs}$ (4) and at $12000 \mathrm{~h}^{-1}$ over $10 \% \mathrm{Co}_{3} \mathrm{O}_{4}$-N-CNFs (5).
Table 4

Activity of the samples after the first heating cycle in the $\mathrm{CO}$ oxidation.

\begin{tabular}{lccc}
\hline \multirow{2}{*}{ Sample } & \multicolumn{2}{c}{$\mathrm{CO}$ conversion (\%) } & \multirow{2}{*}{$T_{100} /{ }^{\circ} \mathrm{C}$} \\
\cline { 2 - 3 } & At $30{ }^{\circ} \mathrm{C}$ & At $80{ }^{\circ} \mathrm{C}$ & 165 \\
$\mathrm{Co}_{3} \mathrm{O}_{4}$ & 60 & 64 & 145 \\
$90 \% \mathrm{Co}_{3} \mathrm{O}_{4}$-CNFs & 80 & 74 & 145 \\
$50 \% \mathrm{Co}_{3} \mathrm{O}_{4}$-CNFs & 34 & 10 & 165 \\
$10 \% \mathrm{Co}_{3} \mathrm{O}_{4}$-CNFs & 0.5 & 3 & \\
\hline
\end{tabular}

also observed in the next heating cycles (Table 4). Note that all samples were also activated and demonstrated similar catalytic behavior after pretreatment with $20 \% \mathrm{O}_{2} / \mathrm{Ar}$ mixture at $200{ }^{\circ} \mathrm{C}$.

\subsection{Capacity properties of $\mathrm{Co}_{3} \mathrm{O}_{4}-\mathrm{N}-\mathrm{CNFS}$}

The volt-ampere curves obtained at different scan rates for a cell with N-CNFs electrode are close to the classical squared shape, which corresponds to carbon nanomaterials (Fig. 8 $[47,48])$. At a scan rate of $10 \mathrm{mV} / \mathrm{s}$, the capacitance is equal to $57 \mathrm{~F} / \mathrm{g}$. Among the studied nanocomposites, only $10 \% \mathrm{Co}_{3} \mathrm{O}_{4}-\mathrm{N}-$ CNFs showed the electrochemical activity. Its capacitance was 1.7 times higher than that of the electrode based on N-CNFs and reached $95 \mathrm{~F} / \mathrm{g}$. In this case, volt-ampere curves deviated from the squared shape and were closer to the curves that are typical of electrodes with pseudocapacitance [23] although no distinct peaks were observed in the studied region of potentials, both for direct and inverse scanning.

\subsection{Discussion}

In this work, the same precipitation method was employed for the synthesis of nanocomposites containing cobalt oxide and N-CNFs; the $\mathrm{Co}_{3} \mathrm{O}_{4}$ content varied from 10 to $90 \mathrm{wt} \%$. The phase composition of the synthesized nanocomposites was constant and was represented by cobalt oxide phases with lattice parameters of 8.06-8.08 $\AA$, which is typical of $\mathrm{Co}_{3} \mathrm{O}_{4}$ spinel, and by the carbon phase. The morphologies of the nanocomposites, state of the surface, and redox ability depend on the composition and determine catalytic and capacity properties. In $90 \% \mathrm{Co}_{3} \mathrm{O}_{4}$-N-CNFs, cobalt oxide nanoparticles do not differ in shape from bulk cobalt oxide particles, whereas in the case of $10 \% \mathrm{Co}_{3} \mathrm{O}_{4}-\mathrm{N}-\mathrm{CNFs}$, the extended monolithic $\mathrm{Co}_{3} \mathrm{O}_{4}$ particles in close contact with $\mathrm{N}-\mathrm{CNF}$ are formed in nanocomposite (Fig. 2 (g)). As the cobalt oxide content in nanocomposite decreases, its surface becomes more reduced because the $\mathrm{Co}^{3+} / \mathrm{Co}^{2+}$ ratio decreases about three-fold compared with $\mathrm{Co}_{3} \mathrm{O}_{4}$. This conclusion is supported by TPR data, which showed that the $10 \% \mathrm{Co}_{3} \mathrm{O}_{4}-\mathrm{N}-\mathrm{CNF}$ nanocomposite has the lowest $\mathrm{H}_{2} / \mathrm{Co}$ ratio (Table 3). A new carbon species with $\mathrm{sp}^{3}$ hybridization was detected in nanocomposites, which differed from $\mathrm{sp}^{2}$ carbon in $\mathrm{N}-\mathrm{CNF}$. This new carbon species is formed during the synthesis, which is accompanied most likely by partial burning of $\mathrm{N}-\mathrm{CNF}$ due to formation of close contacts between cobalt oxide particles and N-CNFs. The partial burning of N-CNFs is supported by DTA data, which showed the appearance of a new low-temperature exothermic peak in nanocomposites at $200{ }^{\circ} \mathrm{C}$ and explained changes in the ratio of $\mathrm{N}$ species with different 

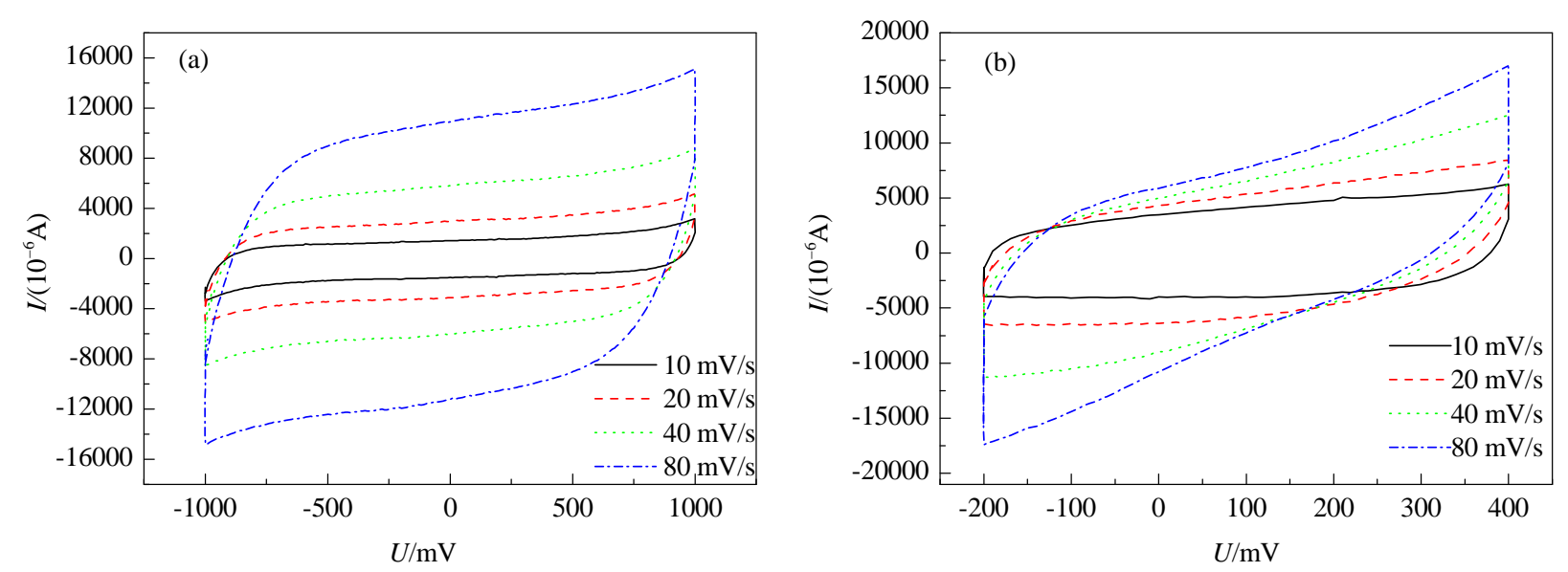

Fig. 8. Cyclic voltammograms of N-CNFs (a) and $10 \% \mathrm{Co}_{3} \mathrm{O}_{4}-\mathrm{N}-\mathrm{CNFs}$ (b) at different voltage sweep rates.

electronic states (Table 2).

The activity of nanocomposites was studied in the CO oxidation. The first heating cycle in the reaction resulted in activation of the samples, which is typical of the oxidation catalysts and is related to the removal of surface deposits. Indeed, maxima of the hydrogen absorption peaks on the TPR curve of activated $\mathrm{Co}_{3} \mathrm{O}_{4}$ shifted toward low temperatures compared with the initial $\mathrm{Co}_{3} \mathrm{O}_{4}$; an additional low-temperature peak, which can be attributed to the reduction of weakly bound oxygen, appeared at $190{ }^{\circ} \mathrm{C}$ (Fig. 6). It is known that activity of $\mathrm{Co}_{3} \mathrm{O}_{4}$ in the $\mathrm{CO}$ oxidation is determined by the amount and stability of $\mathrm{Co}^{3+}$ cations [8]. In reality, the activation of $\mathrm{Co}_{3} \mathrm{O}_{4}$ increased the $\mathrm{H}_{2}$ /Co ratio from 1.18 to 1.45 , indicating an increase in the amount of $\mathrm{Co}^{3+}$; hence, activity of the activated sample was substantially enhanced.

A nonlinear dependence of activity of the activated nanocomposites on the cobalt oxide content was revealed: $10 \%$ $\mathrm{Co}_{3} \mathrm{O}_{4}<50 \% \mathrm{Co}_{3} \mathrm{O}_{4}<100 \% \mathrm{Co}_{3} \mathrm{O}_{4}<90 \% \mathrm{Co}_{3} \mathrm{O}_{4}$. In the $10 \% \mathrm{Co}_{3} \mathrm{O}_{4}-\mathrm{N}-\mathrm{CNF}$ nanocomposite, the amount of $\mathrm{Co}^{2+}$ exceeds that of $\mathrm{Co}^{3+}$, and the $\mathrm{H}_{2} / \mathrm{Co}$ ratio is below the stoichiometric value. Accordingly, this nanocomposite has the lowest activity among all the samples; its activity becomes comparable with other nanocomposites only after decreasing the space velocity of the reaction flow from 240000 to $12000 \mathrm{~h}^{-1}$ (Fig. 7(b)). In the $90 \% \mathrm{Co}_{3} \mathrm{O}_{4}-\mathrm{N}-\mathrm{CNFs}$ nanocomposite, the $\mathrm{Co}^{3+}$ amount is two times higher than that of $\mathrm{Co}^{2+}$ and $\mathrm{H}_{2} / \mathrm{Co}=1.33$, which is close to the ratio typical of $\mathrm{Co}_{3} \mathrm{O}_{4}$. Therewith, the $\mathrm{CO}$ conversion over $90 \% \mathrm{Co}_{3} \mathrm{O}_{4}-\mathrm{N}-\mathrm{CNF}$ at $30{ }^{\circ} \mathrm{C}$ exceeds the $\mathrm{CO}$ conversion over $\mathrm{Co}_{3} \mathrm{O}_{4}$ by $20 \%$ (Table 4). In the study of $\mathrm{Co}_{3} \mathrm{O}_{4}$ supported on CNTs [41], it was suggested that the defect structure of CNTs affects the formation of weakly bound surface oxygen on the $\mathrm{Co}_{3} \mathrm{O}_{4}$ particles and facilitates the oxidation/reduction of cobalt oxide, thus increasing the catalyst activity in the oxidation of toluene. N-CNFs also have a high concentration of defects, which was demonstrated by Raman spectroscopy data; $I_{\mathrm{D}} / I_{\mathrm{G}}$ being equal to 3.3 [28]. In this work, an additional increase in the concentration of defects in N-CNFs of nanocomposites was revealed by XPS, which showed a decreased amount of graphite-like $\mathrm{N}$ and an increased amount of pyrrole $\mathrm{N}$ compared with initial N-CNFs. A minimum ratio of $\mathrm{N}_{\mathrm{Q}} /\left(\mathrm{N}_{\mathrm{Py}}+\mathrm{N}_{\mathrm{Pyr}}\right)$ was observed exactly in the case of $90 \% \mathrm{Co}_{3} \mathrm{O}_{4}-\mathrm{N}-\mathrm{CNF}$. In addition, $\mathrm{N}$-CNFs are the conductive materials; their conductivity reached 15 $\mathrm{S} / \mathrm{cm}$ [28]. These properties of N-CNFs may facilitate the reduction of cobalt oxide and increase the activity of the nanocomposite. Indeed, in comparison with $\mathrm{Co}_{3} \mathrm{O}_{4}$, the doped $90 \% \mathrm{Co}_{3} \mathrm{O}_{4}-\mathrm{N}-\mathrm{CNFs}$ nanocomposite showed a decrease in the temperature of $\mathrm{Co}_{3} \mathrm{O}_{4}$ reduction to $\mathrm{CoO}$ and an additional low-temperature peak corresponding to the reduction of weakly bound oxygen; hence, the activity of $90 \% \mathrm{Co}_{3} \mathrm{O}_{4}-\mathrm{N}-\mathrm{CNF}$ increased.

It should be noted that the temperature curve of CO conversion over the activated samples during the second heating has an unusual U-shape. Such a shape has been reported in the literature $[9,10,49,50]$. A decrease in CO conversion with an increase in reaction temperature on a certain part of the curve indicates that at such temperatures the apparent activation energy has a negative value. The literature does not provide a reliable explanation for such a decrease in the CO conversion with increasing temperature. Two main reasons are discussed now: (1) the rapid deactivation of highly active low-temperature sites due to their reduction and (2) accumulation of the surface carbonate or hydroxyl groups. The results obtained cannot explain the shape of the curve; we accordingly plan to perform additional studies using in situ XPS.

It is known that an increase in capacitance of carbon electrodes with an electric double layer after the introduction of transition metal oxides is caused by Faraday electrode processes that are based on redox reactions [23,51]. For example, the use of $95 \% \mathrm{Co}_{3} \mathrm{O}_{4}$-CNTs electrodes allowed to increase its capacitance by $150 \%$ compared with $\mathrm{Co}_{3} \mathrm{O}_{4}$. Among the samples examined in this work, only the $10 \% \mathrm{Co}_{3} \mathrm{O}_{4}-\mathrm{N}-\mathrm{CNF}$ nanocomposite showed electrochemical activity as a capacitor electrode; its capacitance reached $95 \mathrm{~F} / \mathrm{g}$, which is 1.7 times higher than that of N-CNFs. According to TEM results, in this sample cobalt oxide is distributed homogeneously and the cobalt oxide particles formed interesting extended structures, which strongly contacted with N-CNFs and differed from cobalt oxide particles in other nanocomposites. Evidently, in this case, the electrochemical activity of the nanocomposite is determined primarily by its morphology. 


\section{Conclusions}

$\mathrm{Co}_{3} \mathrm{O}_{4}-\mathrm{N}-\mathrm{CNF}$ nanocomposites were synthesized by the precipitation method. Depending on $\mathrm{Co}_{3} \mathrm{O}_{4}$ content, such nanocomposites had different morphologies in terms of cobalt oxide nanoparticles, their distribution over the bulk, and the $\mathrm{Co}^{3+} / \mathrm{Co}^{2+}$ ratio. We found that $\mathrm{Co}_{3} \mathrm{O}_{4}$ doping using $10 \%$ of $\mathrm{N}$-CNFs increases the activity of bulk cobalt oxide by $20 \%$. We propose that $\mathrm{N}-\mathrm{CNF}$ enhance the ability of $\mathrm{Co}_{3} \mathrm{O}_{4}$ to conduct redox processes because of the substantial increase in the concentration of $\mathrm{N}$-CNF defects in the nanocomposite. In turn, $10 \% \mathrm{Co}_{3} \mathrm{O}_{4}-\mathrm{N}-\mathrm{CNF}$ nanocomposites with specific morphology of cobalt oxide nanoparticles demonstrated electrochemical activity as a supercapacitor electrode.

\section{References}

[1] Casas-Cabanas M, Binotto G, Larcher D, Lecup A, Giordani V, Tarascon J M. Chem Mater, 2009, 21: 1939

[2] Li W Y, Xu L N, Chen J. Adv Funct Mater, 2005, 15: 851

[3] Farhadi S, Safabakhsh J, Zaringhadam P. J Nanostructure Chem, 2013, 3: 69

[4] Wang X, Tian W, Zhai T Y, Zhi C Y, Bando Y, Golberg D. J Mater Chem, 2012, 22: 23310

[5] Royer S, Duprez D. ChemCatChem, 2011, 3: 24

[6] Jansson J. J Catal, 2000, 194: 55

[7] Yu Y B, Takei T, Ohashi H, He H, Zhang X L, Haruta M. J Catal, 2009, 267: 121

[8] Xie X W, Li Y, Liu Z Q, Haruta M, Shen W J. Nature, 2009, 458: 746

[9] Ren Y, Ma Z, Qian L P, Dai S, He H Y, Bruce P G. Catal Lett, 2009, 131: 146

[10] Jia C J, Schwickardi M, Weidenthaler C, Schmidt W, Korhonen S, Weckhuysen B M, Schüth F. J Am Chem Soc, 2011, 133: 11279

[11] Li D B, Liu X H, Zhang Q H, Wang Y, Wan H L. Catal Lett, 2009, 127 377

[12] Tang C W, Wang C B, Chien S H. Catal Lett, 2009, 131: 76
[13] Su D S, Perathoner S, Centi G. Chem Rev, 2013, 113: 5782

[14] Zhu J, Holmen A, Chen D. ChemCatChem, 2013, 5: 378

[15] Su D S, Perathoner S, Centi G. Catal Today, 2012, 186: 1

[16] Bitter J H.J Mater Chem, 2010, 20: 7312

[17] Antolini E. Appl Catal B, 2009, 88: 1

[18] Amadou J, Chizari K, Houlle M, Janowska I, Ersen O, Begin D, Pham-Huu C. Catal Today, 2008, 138: 62

[19] Garcia-Garcia F R, Alvarez-Rodriguez J, Rodriguez-Ramos I, Guerrero-Ruiz A. Carbon, 2010, 48: 267

[20] Bezemer G L, van Laak A, van Dillen A J, de Jong K P. Stud Surf Sci Catal, 2004, 147: 259

[21] Bezemer G L, Radstake P B, Koot V, van Dillen A J, Geus J W, de Jong K P. J Catal, 2006, 237: 291

[22] Lim H D, Gwon H, Kim H, Kim S W, Yoon T, Choi J W, Oh S M, Kang K. Electrochim Acta, 2013, 90:63

[23] Lang J W, Yan X B, Xue Q J.J Power Sources, 2011, 196: 7841

[24] Ewels C P, Glerup M.J Nanosci Nanotechnol, 2005, 5: 1345

[25] Terrones M, Jorio A, Endo M, Rao A M, Kim Y A, Hayashi T, Terrones H, Charlier J C, Dresselhaus G, Dresselhaus M S. Mater Today, 2004, 7(10): 30

[26] van Dommele S, de Jong K P, Bitter J H. Chem Commun, 2006: 4859

[27] Maldonado S, Morin S, Stevenson K J. Carbon, 2006, 44: 1429

[28] Ismagilov Z R, Shalagina A E, Podyacheva O Yu, Ischenko A V, Kibis L S, Boronin A I, Chesalov Y A, Kochubey D I, Romanenko A I, Anikeeva O B, Buryakov T I, Tkachev E N. Carbon, 2009, 47: 1922

[29] Podyacheva O Yu, Ismagilov Z R, Boronin A I, Kibis L S, Slavinskaya E M, Noskov A S, Shikina N V, Ushakov V A, Ischenko A V. Catal Today, 2012, 186: 42

[30] Shalagina A E, Ismagilov Z R, Podyacheva O Yu, Kvon R I, Ushakov V A. Carbon, 2007, 45: 1808

[31] Mateyshina Y, Ulihin A, Samarov A, Barnakov C, Uvarov N. Solid State Ionics, 2013, 251: 59

[32] Hutchings K N, Wilson M, Larsen P A, Cutler R A. Solid State Ionics, 2006, 177: 45

[33] Radwan N R E, El-Shobaky H G. Thermochim Acta, 2000, 360: 147

[34] Dervishi E, Li Z R, Biris A R, Lupu D, Trigwell S, Biris A S. Chem Mater, 2007, 19: 179

\section{Graphical Abstract}

Chin. J. Catal., 2014, 35: 960-969 doi: 10.1016/S1872-2067(14)60099-1

\section{Catalytic and capacity properties of nanocomposites based on cobalt oxide and nitrogen-doped carbon nanofibers}

Olga Yu. Podyacheva*, Andrei I. Stadnichenko, Svetlana A. Yashnik, Olga A. Stonkus, Elena M. Slavinskaya, Andrei I. Boronin, Andrei V. Puzynin, Zinfer R. Ismagilov

Boreskov Institute of Catalysis, Russia; Novosibirsk State University, Russia; Institute of Coal Chemistry and Material Science, Russia
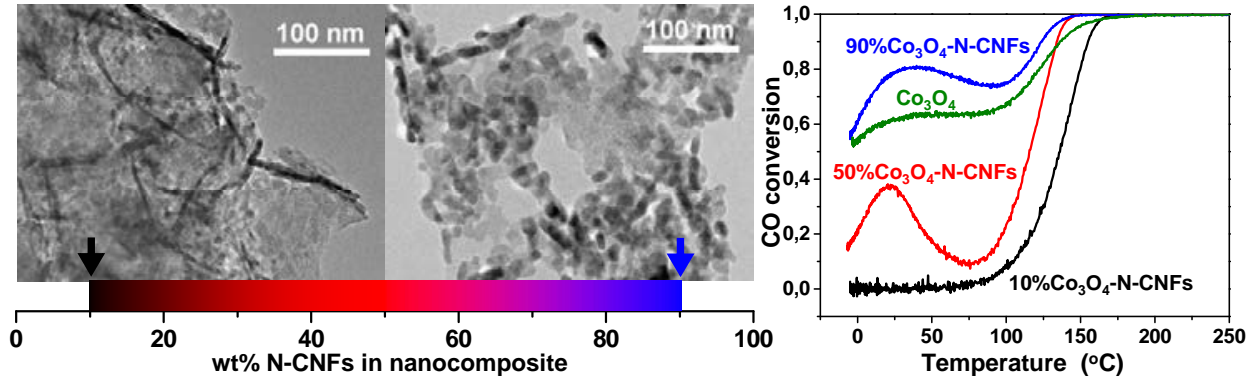

The paper describes the properties of $\mathrm{Co}_{3} \mathrm{O}_{4}-\mathrm{N}$-CNFs nanocomposites: doping of $\mathrm{Co}_{3} \mathrm{O}_{4}$ by $10 \mathrm{wt} \%$ of N-CNFs improves the low-temperature activity of $\mathrm{Co}_{3} \mathrm{O}_{4}$ in $\mathrm{CO}$ oxidation reaction. 
[35] Dervishi E, Li Z R, Watanabe F, Xu Y, Saini V, Biris A R, Biris A S. J Mater Chem, 2009, 19: 3004

[36] Zhang J S, Grzelczak M, Hou Y D, Maeda K, Domen K, Fu X Z, Antoniettu M, Wang X C. Chem Sci, 2012, 3: 443

[37] Chuang T J, Brundle C R, Rice D W. Surf Sci, 1976, 59: 413

[38] Natile M M, Glisenti A. Chem Mater, 2002, 14: 3090

[39] Zhu H W, Razzaq R, Jiang L, Li C S. Catal Commun, 2012, 23: 43

[40] Wang S J, Zhang B P, Zhao C H, Li S J, Zhang M X, Yan L P. Appl Surf Sci, 2011, 257: 3358

[41] Jiang S J, Song S Q. Appl Catal B, 2013, 140-141: 1

[42] Jimenez V M, Fernandez A, Espinos J P, Gonzalez-Elipe A R. J Electron Spectr Rel Phen, 1995, 71: 61

[43] Sexton B A, Hughes A E, Turney T W.J Catal, 1986, 97: 390
[44] Tang C W, Wang C B, Chien S H. Thermochim Acta, 2008, 473: 68

[45] Jacobs G, Ji Y Y, Davis B H, Cronauer D, Kropf A J, Marshall C L. Appl Catal A, 2007, 333: 177

[46] Tomic-Tucakovic B, Majstorovic D, Jelic D, Mentus S. Thermochim Acta, 2012, 541: 15

[47] Hwang S G, Ryu S H, Yun S R, Ko J M, Kim K M, Ryu K S. Mater Chem Phys, 2011, 130: 507

[48] Liu J S, Hu Y, Chuang T L, Huang C L. Thin Solid Films, 2013, 544: 186

[49] Jia C J, Liu Y, Bongard H, Schüth F. J Am Chem Soc, 2010, 132: 1520

[50] Cunningham D A H, Vogel W, Haruta M. Catal Lett, 1999, 63: 43

[51] Liu H L, Wang Y, Gou X L, Qi T, Yang J, Ding Y L. Mater Sci Eng B, 2013, 178: 293 